\title{
The Project Method in Teaching Future Mathematics Teachers
}

\author{
Cherniavskikh S.D., Borisov I.P.,Ostapenko S.I., Tsetsorina T.A.,Sokolskii A.G., Vitokhina N.N.
}

\begin{abstract}
This paper deals with the problem of using the project method in teaching future mathematics teachers. The new educational strategy implements self-education with the help of developing technologies, the goal of which is not only to bring knowledge to students, but also to identify and develop the creative interests and abilities of each student, to stimulate his/her independent productive learning activities. The authors showed that one of such technologies is project training, which involves joint learning and cognitive activity of students, having a common goal, agreed ways of working. This paper notes also the need to use project technology, which consists in developing the ability of future teachers to have an analytical, creative thinking; self-acquisition of missing math knowledge from various sources; thinking, based on knowledge of mathematical facts, the laws of science; and ability to work in a team, performing various social roles.

Keywords: project, project technology, project method, future teachers, research.
\end{abstract}

\section{INTRODUCTION}

Today, theoretical knowledge is not enough for a future teacher - a thriving science leads to their rapid obsolescence. Science and practice of educational activities offers a large variety of pedagogical technologies that are recommended for the formation of competences of future teachers. One of the pedagogical technologies that allows organizing such training is project technology (method of projects, project method, project technology, project training technology)

The project method is a way to achieve a didactic goal through the detailed development of the problem, which ends with a real, tangible practical result, executed in a certain way (E.S. Polat) [4]. The main purpose of the project method is to provide students with the opportunity to independently acquire knowledge and skills in the process of solving the problem posed, requiring the integration of knowledge from various subject areas.

Revised Manuscript Received on July 22, 2019.

Cherniavskikh S.D., Belgorod State University, 85, Pobedy St., Belgorod, 308015, Russia

Borisov I.P., Belgorod State University, 85, Pobedy St., Belgorod, 308015, Russia

Ostapenko S.I., Belgorod State University, 85, Pobedy St., Belgorod, 308015, Russia

Tsetsorina T.A., Belgorod State University, 85, Pobedy St., Belgorod, 308015, Russia

Sokolskii A.G., Belgorod State University, 85, Pobedy St., Belgorod, 308015, Russia

Vitokhina N.N., Belgorod State University, 85, Pobedy St., Belgorod, 308015, Russia
The essence of this method in teaching future mathematics teachers is to stimulate the interest of future teachers in certain mathematical problems, the solution of which involves both possession of a certain amount of knowledge and, through design activities, and practical application of existing and acquired knowledge [10]. This method allows actually combining theoretical knowledge with practical experience of their use in teaching future mathematics teachers. This project for a student is an opportunity to maximize his/her creative potential, a means of selfrealization. This is an activity that allows expressing oneself individually or in a group, try have a shot, apply knowledge, benefit, show achieved results publicly. For a teacher, an educational project is an integrative didactic means of development, training and education, which allows for the development of specific skills and abilities of project activities, as well as the joint search for information, selfstudy, research and creative activities $[6,8,9]$.

\section{MAIN PART}

Within the framework of the competence-based approach, content for students is valuable, meaningful, interesting, and has an applied character. The interaction of the teacher and students is based on parity: the teacher performs the function of the organizer of the educational process (tutor), while the students mostly work independently (look for the necessary information, analyze it, process it, present it, make decisions in non-standard situations, set a goal, make a plan to achieve it, implement this plan, put forward and prove hypotheses, etc.) $[5,11]$.

The project method involves a system of actions of the teacher and students to develop a certain project. The project, translated from the Latin as "thrown forward" - is the interrelation of two factors: design and implementation. In the pedagogical literature and the practice of teaching, the "project" is understood in different ways. On the one hand, it is interpreted as a result of students' activities. On the other hand, it is "learning through doing" (J. Dewey), a form of organization of activity, as a result of which students will definitely get the final specific result (V.V. Guzeev) $[1,2]$.

The project method in teaching future mathematics teachers can be divided into stages:

1. Preparatory. This stage involves selection of the topic and objectives of the project, as well as determining the number of project participants, the composition of groups. Future teachers discuss the established theme of the project with the teacher, receive additional information if necessary, set goals. The teacher motivates students, helps in setting goals [1, p. 175-177].

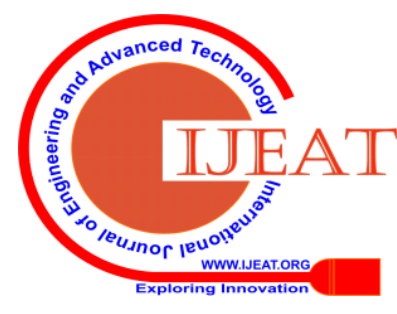




\section{The Project Method in Teaching Future Mathematics Teachers}

2. Analytical (work planning). At this stage, the sources of information are determined that are necessary to obtain knowledge of the mathematical design object; planning of ways to collect and analyze the information received; planning of the implementation of the final product (result presentation form): a newspaper issue, an oral report with a demonstration of materials; establishing criteria for evaluating results; distribution of responsibilities among the members of the group involved in the project in mathematics. Students develop an action plan. The teacher offers ideas, makes assumptions, determines the terms of work on each stage and the project in general.

3. Practical (research activities). This stage involves summation of information collected by each of the students during their participation in the project. Future teachers are conducting research. The teacher observes, advises, directs the work, organizes and coordinates, if necessary, the activities of students.

4. Presentation stage. At this stage, the presentation of the finished product to a wide audience of listeners takes place. Classmates, students from other groups, teachers, students and other invited guests can play the role of such students. The results of the project can be also presented in the form of a conference.

5. Results. Summarization: forming of the result. At the final design stage, future teachers form their results obtained during the study. The activity of the teacher at this stage will be observation, provision of necessary advice, grading or scoring $[2$, p. 76$]$.

Table 1. Requirements for the content of educational and research work of future mathematics teachers

\begin{tabular}{|l|l|}
\hline Structure & Requirements for the content \\
\hline Title sheet & $\begin{array}{l}\text { Contains: } \\
- \text { number of the group which performed the work; } \\
- \text { author's name; } \\
- \text { topic of the work; } \\
- \text { tutor's name. }\end{array}$ \\
\hline Table of contents & Includes the titles of all chapters, sections, indicating their number of pages \\
\hline Introduction & $\begin{array}{l}\text { Contains: } \\
- \text { relevance; } \\
- \text { project object; } \\
- \text { goal; } \\
- \text { tasks; } \\
- \text { research methods; } \\
- \text { practical significance. }\end{array}$ \\
\hline Main part $($ max. & $\begin{array}{l}\text { Consists of chapters that contain material on the specifically studied topic, as well as } \\
\text { information about the final result. }\end{array}$ \\
\hline Summary & $\begin{array}{l}\text { The brief summary of the results of the work performed should consist of several points } \\
\text { summarizing the work done. }\end{array}$ \\
\hline $\begin{array}{l}\text { List } \\
\text { of references }\end{array}$ & \begin{tabular}{l} 
Should contain a list of sources used in writing the project work. \\
\hline Appendixes
\end{tabular} \\
\hline
\end{tabular}

We shall consider the way of studying mathematical problems during project activities. The following can be offered for future teachers:

1. Think up (or select) and solve a mathematical problem on the topic in question in several ways; analyze the decisions and make a conclusion about the rationality of one or another method.

2. Compose and solve a problem with a changing content of the condition or with an unstated question; to analyze how the decision will change when a part of the condition or question changes.

3. Formulate a problem in general form, and, when solving it, select and solve a series of smaller problems [2].

In order to generalize and systematize the school course of mathematics and to implement it at a new level (from the perspective of the future teacher), in the course of teaching methods in mathematics and studying sections of elementary mathematics, you can use group training projects devoted to a deeper study of the subject mathematical content. Topics for these projects can be formulated as follows: "Methods for solving irrational equations: standard and non-standard"; "Equations and inequalities with a module: methods of solution" etc. In the course of the project, students independently plan work, distribute duties, select material, draw up work results. The results of the work on the project are presented in the course of public defense.

For the formation of readiness for pedagogical activity in the course of studying the methodology, it is advisable to use educational projects involving the use of knowledge of a number of related disciplines: pedagogy, psychology, methods of teaching mathematics. Thus, the topic of such an educational project may sound as follows: "Techniques for motivating students in mathematics classes". This project may involve both theoretical studies the study of various methods of students' motivation in the literature, while analyzing the experience of other teachers, and practical - diagnosing students' motivation, conducting an experiment to increase motivation, which can be carried out, for example, in the course of teaching practice. Such projects are long-term and can be both group and individual.

Published By: 
Another example of the implementation of project technology in the training of future teachers can serve as a group of projects on the modeling of professional activity. These projects are usually individual. In the course of their implementation, students prepare and submit fragments of training sessions, primarily to study new material. The students' task is to prepare a fragment of a lesson in mathematics, containing an explanation of the new material, and to present it imitating a real activity, during a class. When implementing this project, at the stage of its presentation and protection, elements of a professional game are introduced. A group of students first acts as students, then as experts, assessing the quality of performance on a number of criteria developed in advance.

The method of projects in the training of future teachers of mathematics always involves solving a problem. This may be the solution of the problem in the best way, the proof of a fact or a theorem, the study of the current state of mathematical knowledge on a topical issue. When implementing the project, the future teacher should conduct a significant research work, process a large number of information sources, which contributes to the improvement of learning motivation and the accumulation of factual knowledge, as well as the development of students' information and communication competencies. Using the project method of teaching future mathematics teachers can increase the degree of autonomy, initiative of students and their cognitive competence, contribute to the acquisition of creative experience, fostering positive value orientations, human qualities, aesthetic taste, information literacy and talent in general.

The inclusion of future teachers of mathematics in the project activity allows transforming theoretical knowledge into professional experience and creates conditions for the self-development of the individual, for personal creative fulfillment that ultimately forms the general and professional-pedagogical competence of students.

\section{CONCLUSION}

The new educational strategy implements self-education with the help of developing technologies, the goal of which is not only to bring knowledge to students, but also to identify and develop the creative interests and abilities of each student, to stimulate his/her independent productive learning activities. The authors showed that one of such technologies is project training, which involves joint learning and cognitive activity of students, having a common goal, agreed ways of working. This paper notes also the need to use project technology, which consists in developing the ability of future teachers to have an analytical, creative thinking; self-acquisition of missing math knowledge from various sources; thinking, based on knowledge of mathematical facts, the laws of science; and ability to work in a team, performing various social roles.

\section{REFERENCES:}

1. Golub G.B. Method of projects - a technology of competence-oriented education [Text]. / G.B. Golub. - Samara: Educational literature, 2006. - $176 \mathrm{p}$.

2. Dubrovina O.S. The use of project technologies in the formation of general and professional competencies of students. Problems and prospects of development of education (II): materials of the
International extra-mural scientific conference (Perm, May 2012). Perm: Mercury, 2012. - P. 124-126.

3. Kolesnikova I.A. Pedagogical design. M.: Akademiia, 2007.

4. Kostrova Iu.S. Method of projects in higher mathematics classes in the context of the competence approach // Molodoi Uchenyi. - 2011. No.8. V.2. - P. 114-117. - URL https://moluch.ru/archive/31/3550/ (accessed date: 02/14/2019).

5. Lazarev T. Project method: application mistakes// Pervoe Sentiabria. 2011. No.1. P. 9-10.

6. Lashtabova N.V. Design and method of projects in the modern educational process of secondary and higher schools // Theories, content and technology of higher education in the context of globalization of the educational process. Orenburg, 2006. Part 1: Sections of General Pedagogy and Pedagogy of Higher Education.

7. Mitrofanova G.G. The difficulties of using project activities in training // Molodoi Uchenyi. 2011. No.5. V.2. P. 148-151.

8. Pakhomova N.Iu. Method of educational project in an educational institution: a study guide for teachers and students of pedagogical universities. M., 2003.

9. Pokushalova L.V. Formation of abilities and development of skills of independent work of students of a technical college // Young scientist. 2011. No.4. V.2. P. 115-117.

10. Prokopieva N.I. Project training in foreign pedagogy. Towards the question of formation and development // Siberian teacher. 2004. No.2. March-April. URL: www.websib.ru

11. Sergeev I.S. How to organize project activities of students [Text]. / I.S. Sergeev. - M.: ARKTIKI, 2007. - 80 p.

12. Silina S.N. Professional-graphical monitoring of the formation of a specialist in the educational process of a pedagogical university: Author's abstract, MD Pedagogy: 13.00.08: Ekaterinburg, 2002.

13. Stupnitskaia M.A. New pedagogical technologies: organization and content of project activities of students: lectures. M.: Publishing House of Moscow Pedagogic University, 2009. p. 132.

14. Khasanova M.L., Aksenova L.N., Rudnev V.V. Improving the quality of practical training of specialists through the use of algorithmic teaching methods [Text] / Modern higher education: an innovative aspect. 2016. V.8. No.3 (33). P. 121-126. 